\title{
The Ecosystem Services Gradient: A Descriptive Model for Identifying Levels of Meaningful Change
}

\author{
Susan Yee, Giancarlo Cicchetti, Theodore H. DeWitt, Matthew C. Harwell, \\ Susan K. Jackson, Margherita Pryor, Kenneth Rocha, Deborah L. Santavy, \\ Leah Sharpe, and Emily Shumchenia
}

\begin{abstract}
Characterization of ecosystem services can be a valuable element of Ecosystem-Based Management (EBM) in identifying meaningful measures of ecosystem change, understanding the natural resource gains or losses associated with changing ecosystem conditions, and communicating those benefits and tradeoffs to stakeholders in an intuitive way. Here, we introduce a descriptive model of the Ecosystem Services Gradient (ESG) that can be paired with the Biological Condition Gradient (BCG). The BCG is a conceptual framework that allows scientists and managers to characterize the status of an aquatic ecosystem along an anthropogenic disturbance gradient by describing and quantifying changes in biological or ecological condition with increasing levels of stressors. The ESG descriptive model builds upon the BCG approach by linking changes in ecosystem condition to effects on human health and well-being via changes in ecosystem goods and services. This involves identifying priority ecosystem services, defining them with metrics and indicators, and applying ecological production functions to translate levels of
\end{abstract}

S. Yee $(\bowtie) \cdot$ M. C. Harwell $~$ D. L. Santavy $\cdot$ L. Sharpe

Gulf Ecosystem Measurement and Modeling Division, US Environmental Protection Agency,

Gulf Breeze, FL, USA

e-mail: yee.susan@epa.gov

G. Cicchetti $\cdot$ K. Rocha

Atlantic Coastal Environmental Sciences Division, US Environmental Protection Agency,

Narragansett, RI, USA

T. H. DeWitt

Pacific Ecological Systems Division, US Environmental Protection Agency, Newport, OR, USA

\section{S. K. Jackson}

Health and Ecological Criteria Division, Office of Water, US Environmental Protection Agency, Washington, DC, USA

M. Pryor

Water Division, Region 1, US Environmental Protection Agency, Boston, MA, USA

E. Shumchenia

E\&C Enviroscape, LLC, Ashaway, RI, USA

(C) The Author(s) 2020

T. G. O'Higgins et al. (eds.), Ecosystem-Based Management, Ecosystem Services and Aquatic Biodiversity, https://doi.org/10.1007/978-3-030-45843-0_15 
ecological condition to ecosystem services production. The ESG, through its structured approach to defining and enumerating potential changes in ecosystem services, allows decision makers to clearly assess and monitor the potential benefits, or related co-occurring benefits, of EBM, and significantly enhance how scientists and decision makers communicate these benefits to stakeholders.

\section{Lessons Learned}

- An Ecosystem Services Gradient (ESG) is introduced to describe the complete range of potential ecosystem services along a gradient of changing environmental condition

- The ESG approach leverages the concept of Final Ecosystem Goods and Services (FEGS) to identify metrics that are directly relevant to human beneficiaries

- An ESG can allow decision makers to describe meaningful and unambiguous measures that clearly communicate the potential gains or losses in ecosystem services

- The ESG facilitates a consideration of potential tradeoffs, or co-benefits, across multiple stakeholder objectives as part of EBM planning and implementation

\section{Needs to Advance EBM}

- Additional scientific research is needed to move from a narrative description of an ESG to a quantitative description that enumerates ecosystem services production with changing levels of condition

- Further development of the ESG approach is needed through case study examples across a range of ecosystem types and EBM applications

\section{Ecosystem-Based Management Objectives and Tradeoffs}

Ecosystem-Based Management (EBM) aims to maintain ecosystems in a healthy and resilient condition while providing the services that humans want and need (McLeod et al. 2005). However, ecosystems are complex, and layering on social and economic considerations can make operationalizing EBM seem intractable (Arkema et al. 2006; Link and Browman 2017). For successful implementation of EBM, there is a specific need to bound the scope of the problem by clarifying what really matters about a decision, including explicitly articulating how objectives will be measured and characterizing values-based tradeoffs among them (Gregory et al. 2012). To address this need, we propose a science-based descriptive model of ecosystem services production in response to changing environmental condition, the Ecosystem 
Services Gradient (ESG). Scientific tools and approaches, like the ESG, can help to operationalize EBM in the decision-making process by identifying meaningful measures, defining reference points, communicating and monitoring the relevant social and economic impacts of actions, and evaluating tradeoffs across multi-sector objectives (Arkema et al. 2006; Cormier et al. 2017).

The conceptual foundation for an ESG follows that of the Biological Condition Gradient (BCG), developed over a decade ago in response to growing need to assess and effectively communicate levels of biological condition in a meaningful way (Davies and Jackson 2006; U.S. EPA 2016). The BCG leverages expert knowledge and biomonitoring data to describe ecological condition along a gradient from undisturbed to severely altered conditions. Our goal in creating an ESG framework is to build upon the original goals in developing the BCG: to create a common framework, based on measurable ecologically important attributes, that can be used to describe the complete range of condition, and provide a rational and consistent means for setting targets and communicating the consequences of different management choices.

The ESG leverages a number of practical strategies for integrating ecosystem services into decision-making, including: (1) prioritizing information and analysis to what is most important; (2) using the concept of final ecosystem goods and services (FEGS) to identify metrics that are unambiguous and directly relevant to human beneficiaries; (3) applying ecosystem services production functions (EPFs) to link changing condition to changes in ecosystem services; (4) understanding the range of potential outcomes; and (5) considering values-based tradeoffs across multiple, often competing, objectives (Yee et al. 2017). In this chapter, we present the conceptual foundation for the ESG as an analogy to the BCG and provide examples of how it is being developed to facilitate EBM.

\section{Conceptual Foundation: The Biological Condition Gradient (BCG)}

The BCG is a descriptive model that describes how attributes of biological condition change in response to increasing levels of anthropogenic stress (Fig. 1a; Davies and Jackson 2006). The BCG approach was developed to address a need for sciencebased approaches to more precisely and effectively communicate the existing and potential condition of aquatic resources for water quality management purposes under the U.S. Clean Water Act (United States Code title 33, sections 1251-1387). The biological characteristics, defined in the BCG as "attributes," include aspects of community structure, non-native taxa, organism condition, ecosystem function, and inter-habitat connectivity. The highest level of biological condition is Level 1, which represents natural or undisturbed biological communities and anchors the best condition for defining five levels of change or departure from this condition. Level 6 represents conditions most severely altered by anthropogenic 

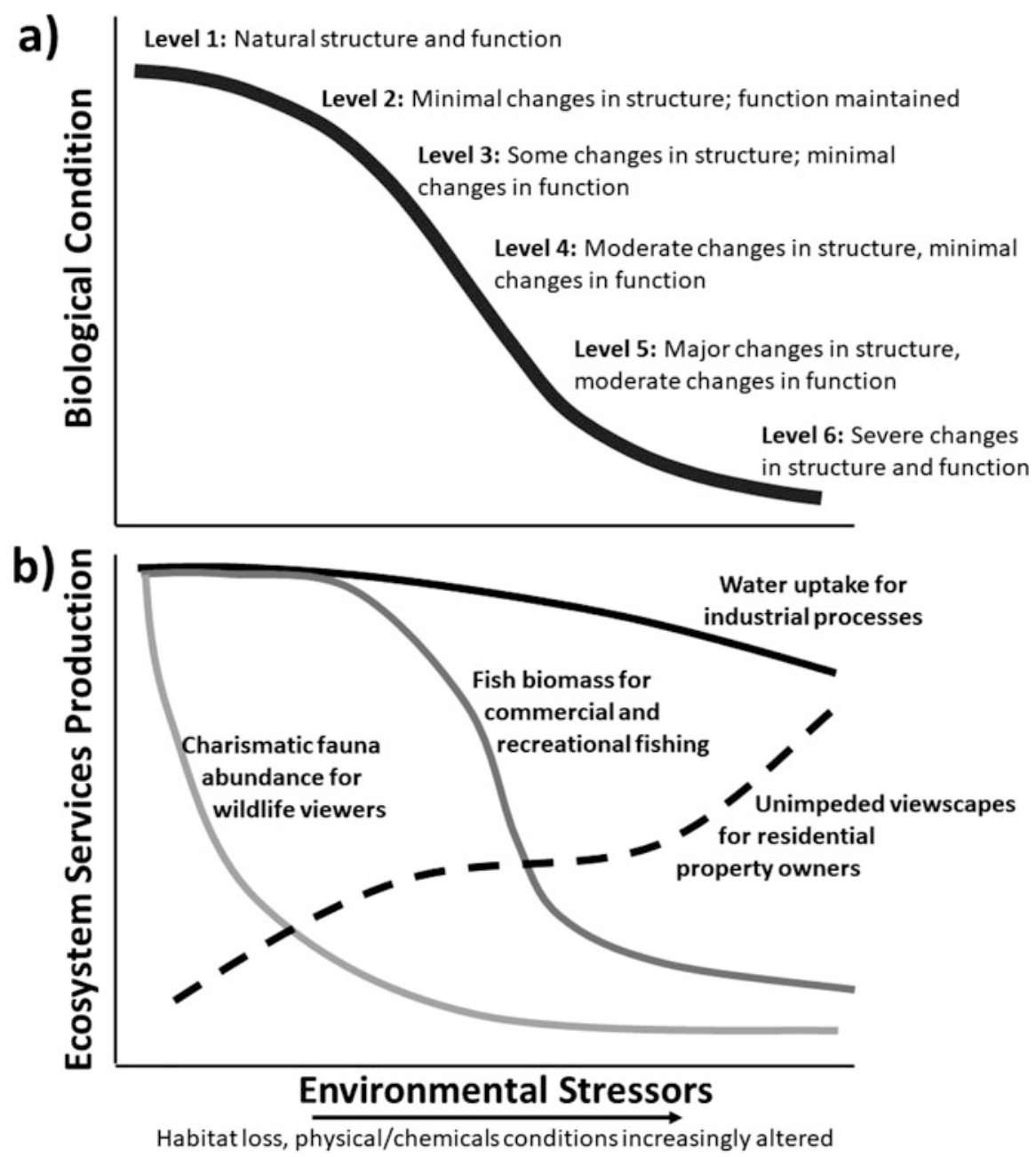

Fig. 1 The BCG model (a; top panel) of incremental changes in biological condition along a stressor gradient, and hypothetical changes in select ecosystem services (b; bottom panel) along the same gradient

stress. Each level is defined by an empirically-derived narrative description that can be consistently interpreted regardless of biology, location, or sampling method. A quantitative model is derived from narrative descriptions for each level and translated using metrics and measurable indicators to develop quantitative decision rules to identify thresholds to discriminate between BCG levels (for details see U.S. EPA 2016; Cicchetti et al. 2017).

In BCG development, a specific sequence of steps is undertaken for a given ecosystem to develop the BCG components (Table 1; U.S. EPA 2016). Because this structured approach is generalizable, BCG models can and have been developed for 
Table 1 Steps in the process of developing and using a BCG

\begin{tabular}{l|l}
\hline $\begin{array}{l}\text { Biological Condition Gradient } \\
\text { framework }\end{array}$ & Process \\
\hline What biological attributes are relevant? & Identify and prioritize attributes \\
\hline How will we measure them? & Identify metrics and indicators \\
\hline What biological condition did we have? & Establish reference (natural) condition \\
\hline $\begin{array}{l}\text { What biological condition do we have } \\
\text { now? }\end{array}$ & Collect and review bioassessment data \\
\hline What biological condition do we want? & Set targets \\
\hline How do we get there? & Identify management actions \\
\hline $\begin{array}{l}\text { What are the social and economic } \\
\text { consequences? }\end{array}$ & $\begin{array}{l}\text { Conduct and communicate ecosystem services } \\
\text { assessment }(E S G)\end{array}$ \\
\hline Adaped from
\end{tabular}

Adapted from Cicchetti et al. 2017

An additional step (in italics) indicates where an assessment of ecosystem services could supplement the process, and in conjunction with stressor and other data, inform management decisions

different regions and different ecosystems, including streams (Davies and Jackson 2006), estuaries (Cicchetti et al. 2017), and coral reefs (Bradley et al. 2014; Santavy et al. 2016). Though originally developed for aquatic ecosystems, the approach is applicable in terrestrial ecosystems as well.

The BCG can help precisely define biological condition, identify and protect high quality waters, evaluate the potential for improvement of degraded waters, select restoration targets, and clearly communicate the likely impacts of management decisions to the public. The additional step of assessing how ecosystem services change with corresponding levels of BCG (Fig. 1b) can help to communicate the social and economic benefits of protecting or restoring a site, or potential tradeoffs between different management scenarios (Cicchetti et al. 2017).

\section{The Ecosystem Services Gradient (ESG)}

\subsection{Interpreting the ESG}

Building on the conceptual foundation of the BCG, the ESG describes the complete range of ecosystem services along a gradient of biological condition from natural to severely altered. In environmental management situations where protecting biological integrity is the primary goal, directly pairing an ESG with a BCG can help decision-makers understand the potential co-occurring benefits and tradeoffs of management activities and communicate them to the public (Fig. 1). Furthermore, if a waterbody is designated for a particular use, such as recreational fisheries or contact recreation, an assessment of ecosystem services in conjunction with BCG can help identify the levels of biological condition that can be protected while still supporting desired levels of services (Davies and Jackson 2006). 
Along a gradient of declining biological condition, ecosystem services may decline at different rates depending on the biological attributes providing those services (Fig. 1b). The quality of a recreational fishery, for example, may depend on the presence of uncommon taxa that are particularly vulnerable to stressors, whereas commercially-important fish species may be able to persist with some moderate degree of habitat degradation. Other ecosystem services may remain relatively unaffected along the gradient if the attributes that define biological condition are disconnected ecologically from the attributes providing the service. For example, the ecosystem service of water availability for use in industrial applications may be only partially influenced by ecosystem condition. Other ecosystem services might increase with declining biological condition. For example, depending on what local residents or recreational users consider to be aesthetically pleasing, charismatic species or unimpeded viewscapes may increase in value as presence of habitat or condition declines.

Operationally, an ESG may be directly paired with a BCG (Fig. 1). Table 1 describes an approach where an added step to the BCG process, ideally occurring during BCG development, could involve an assessment of ecosystem services. However, because the attributes that define biological condition in the BCG may not be the same attributes providing ecosystem services, EBM practitioners may prefer to develop an ESG independently of a BCG. Analogous to a BCG, the ESG would describe the full range of potential ecosystem services provisioning along a stressor gradient. Moreover, different biological attributes contribute to different ecosystem services, such that a suite of ESG curves may be needed for describing a range of different ecosystem services in a given system. However, the underlying approach in building the ESG is the same regardless, differing only in how the descriptive model is presented as either a gradient of decreasing biological condition or a gradient of changing service production (Fig. 1).

\subsection{Steps for Developing an ESG}

The steps to building and using an ESG closely parallel the steps to develop and use a BCG (Table 2). An important first step is working with decision makers and stakeholders to identify the relevant ecosystem services for the specific environmental management problem. A FEGS approach can help reduce ambiguity by explicitly and directly connecting biophysical indicators to the people that benefit from them (Fig. 2; Boyd et al. 2015; DeWitt et al. 2020). Along a continuum of ecological production, FEGS are distinguished from intermediate regulating and supporting ecological functions (e.g., habitat quality, water quality) that require additional steps to reach the ecological features (e.g., harvestable fish) directly experienced by human beneficiaries (Landers and Nahlik 2013).

Monitoring data on FEGS metrics form the basis for quantitatively describing levels of production from highest potential production to severely altered production along a gradient of changing environmental condition. While environmental 
Table 2 Steps in the process of developing and using an ESG

\begin{tabular}{l|l}
\hline $\begin{array}{l}\text { Ecosystem Services Gradient } \\
\text { Framework }\end{array}$ & Process \\
\hline $\begin{array}{l}\text { What final ecosystem goods and ser- } \\
\text { vices (FEGS) are relevant? }\end{array}$ & Identify and prioritize FEGS \\
\hline How will we measure them? & $\begin{array}{l}\text { Identify FEGS metrics and indicators, and the bio- } \\
\text { physical attributes that provide them }\end{array}$ \\
\hline What FEGS could we have? & $\begin{array}{l}\text { Establish potential availability under a range of } \\
\text { bio-physical conditions }\end{array}$ \\
\hline What FEGS do we have now? & $\begin{array}{l}\text { Measuring, mapping, and ecological production func- } \\
\text { tions (EPFs) }\end{array}$ \\
\hline What FEGS do we want? & Evaluate co-occurring benefits and tradeoffs \\
\hline How do we get there? & Identify management actions \\
\hline $\begin{array}{l}\text { What are the social and economic } \\
\text { consequences? }\end{array}$ & $\begin{array}{l}\text { Conduct and communicate benefits assessment using } \\
\text { ecological benefit functions (EBFs) }\end{array}$ \\
\hline
\end{tabular}

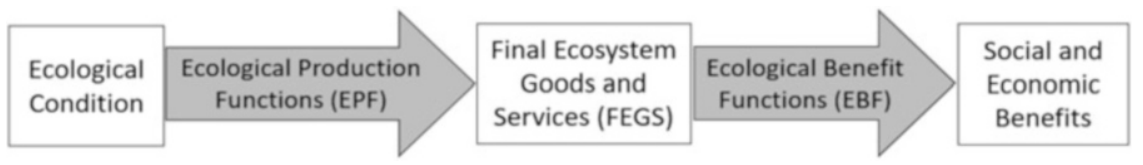

Fig. 2 Conceptual model illustrating the relationships between ecological condition, FEGS, and socio-economic benefits

assessments and monitoring often focus on collecting data on ecological condition, development of an ESG may rely on reasonable proxies where direct data or models are not available. Models, known as ecological production functions (EPFs), may be needed to translate environmental condition data to FEGS metrics (Fig. 2; Wainger and Mazzotta 2011; Bruins et al. 2017). This combination of expert judgment on meaningful metrics, collection of field data, and application of EPFs is used to first narratively and then, ideally, numerically describe incremental changes in ecosystem services provisioning along a stressor gradient to form the ESG. If ESGs are developed for more than one ecosystem service (e.g., Fig. 1b), then potential co-occurring benefits or tradeoffs can be examined alongside changes in ecosystem condition.

While FEGS represent the end product of what the environment provides to human beneficiaries, they require human input and interaction (e.g., a boat to collect the fish) for those services to be realized as actual benefits (Mazzotta et al. 2016). As such, a benefits assessment, using ecological benefits functions (EBFs) to translate ecosystem service supply into monetary, health, or other measures of benefit, could be an additional step for characterizing and communicating the benefits of EBM decisions (Fig. 2). 


\section{Example ESG Applications}

\subsection{Communicating Benefits of Coral Reef Protection}

Healthy coral reef ecosystems supply multitudes of benefits on which many economies and societies rely (Wilkinson 2008; van Beukering et al. 2011), including recreation such as fishing, tourism, boating, SCUBA diving; education; coastal protection; and bioprospecting for novel pharmaceuticals and biochemicals (Moberg and Folke 1999; Principe et al. 2012). Marine coastal areas, including coral reefs, are exposed to increasing loads of nutrients, sediments, pollutants, and other materials originating from terrestrial sources that can deleteriously impact the ecosystem goods and services they provide and place them at risk of being lost (Harborne et al. 2017). Consequently, there is continuing urgency to develop tools to effectively communicate this information to improve public awareness of reef condition; understand what actions are most likely to protect these irreplaceable ecosystems; and provide a more robust process to inform management of the biological condition of coral reefs to ensure protection of high quality marine waters and their biological communities, and to develop restoration targets.

The framework used to develop the BCG model for freshwater streams, rivers, and lakes was adapted to incorporate coral reef attributes judged important to protect the biological integrity of tropical Caribbean and Western Atlantic waters, including marine coastal habitats such as mangroves, seagrasses, and coral reefs (Bradley et al. 2014; Santavy et al. 2016). From a preliminary narrative model of all coral reef assemblages (Table 3), two narrative BCG models were developed for Caribbean coral reefs, one for coral reef fish and a second for sessile marine assemblages, built primarily using attributes from scleractinian coral communities, but including algae, sponges, and octocorals (Santavy et al. 2016). For each, a numeric BCG model is being developed by eliciting expert knowledge in combination with bioassessment data and underwater videos, using mathematical fuzzy set theory to define decision rules for BCG levels (U.S. EPA 2016).

In order to build upon these coral reef BCGs and develop an ESG for coral reefs, the first step would be to identify the most relevant ecosystem goods and services for the particular decision context (Table 2), recognizing that ESGs would need to be developed on a site-by-site basis so that each ESG properly reflects the makeup of human beneficiaries at that site. For example, a coral reef that is situated within a Marine Protected Area that limits or bans many consumptive activities will provide a very different set of FEGS than a coral reef that has fewer use restrictions. Once the stakeholder groups associated with the reef have been clearly identified, the ways in which each of those groups benefit from the reef can be identified and clearly articulated. At this point, the FEGS necessary to achieve those benefits can be identified. This can be done in an ad hoc fashion or using a more structured approach such as the National Ecosystem Services Classification System (U.S. EPA 2015) or the Common International Classification of Ecosystem Services (CICES; HainesYoung and Potschin 2018) as a starting point to identify potential FEGS. Because 
Table 3 Examples of narrative condition levels and associated attributes in coral reef BCG

\begin{tabular}{|c|c|c|c|c|c|}
\hline $\begin{array}{l}\text { Condition } \\
\text { level }\end{array}$ & $\begin{array}{l}\text { Physical } \\
\text { structure }\end{array}$ & Corals & $\begin{array}{l}\text { Fish, other } \\
\text { vertebrates and } \\
\text { invertebrates }\end{array}$ & $\begin{array}{l}\text { Gorgonians, } \\
\text { sponges, algae }\end{array}$ & Condition \\
\hline $\begin{array}{l}\text { Very } \\
\text { Good } \\
\text { Excellent } \\
\text { BCG } \\
\text { Level 1-2 } \\
\end{array}$ & $\begin{array}{l}\text { High rugos- } \\
\text { ity; very } \\
\text { clear water; } \\
\text { no sediment }\end{array}$ & $\begin{array}{l}\text { High species } \\
\text { diversity; } \\
\text { includes rare, } \\
\text { large, and old } \\
\text { colonies }\end{array}$ & $\begin{array}{l}\text { Balanced spe- } \\
\text { cies abundances } \\
\text { and sizes; large, } \\
\text { long-lived spe- } \\
\text { cies present }\end{array}$ & $\begin{array}{l}\text { Low abun- } \\
\text { dance of fleshy } \\
\text { algae; sensi- } \\
\text { tive species } \\
\text { present }\end{array}$ & $\begin{array}{l}\text { Low preva- } \\
\text { lence of } \\
\text { disease }\end{array}$ \\
\hline $\begin{array}{l}\text { Good } \\
\text { BCG } \\
\text { Level } 3\end{array}$ & $\begin{array}{l}\text { Moderate to } \\
\text { high rugos- } \\
\text { ity; water } \\
\text { slightly tur- } \\
\text { bid; low } \\
\text { sediment }\end{array}$ & $\begin{array}{l}\text { Moderate coral } \\
\text { diversity; rare } \\
\text { species absent }\end{array}$ & $\begin{array}{l}\text { Noticeable } \\
\text { decline in apex } \\
\text { predators; large, } \\
\text { long lived spe- } \\
\text { cies absent } \\
\text { locally }\end{array}$ & $\begin{array}{l}\text { More fleshy } \\
\text { algae than } \\
\text { Level 1-2; } \\
\text { highly sensi- } \\
\text { tive species } \\
\text { missing }\end{array}$ & $\begin{array}{l}\text { Disease } \\
\text { slightly } \\
\text { above back- } \\
\text { ground } \\
\text { level; some } \\
\text { irregular tis- } \\
\text { sue loss }\end{array}$ \\
\hline $\begin{array}{l}\text { Fair } \\
\text { BCG } \\
\text { Level } 4\end{array}$ & $\begin{array}{l}\text { Low rugos- } \\
\text { ity; water } \\
\text { turbid; sedi- } \\
\text { ment } \\
\text { accumulation }\end{array}$ & $\begin{array}{l}\text { Reduced coral } \\
\text { diversity; few } \\
\text { or no living, } \\
\text { large, old colo- } \\
\text { nies; emer- } \\
\text { gence of } \\
\text { tolerant species }\end{array}$ & $\begin{array}{l}\text { Absence of } \\
\text { small reef } \\
\text { fishes; large, } \\
\text { long lived spe- } \\
\text { cies absent } \\
\text { locally; sensi- } \\
\text { tive species } \\
\text { conspicuously } \\
\text { absent }\end{array}$ & $\begin{array}{l}\text { Gorgonians } \\
\text { replace sensi- } \\
\text { tive coral and } \\
\text { sponge spe- } \\
\text { cies; abundant } \\
\text { and diverse } \\
\text { fleshy algae }\end{array}$ & $\begin{array}{l}\text { Higher } \\
\text { prevalence } \\
\text { of disease } \\
\text { and tissue } \\
\text { loss }\end{array}$ \\
\hline $\begin{array}{l}\text { Poor } \\
\text { BCG } \\
\text { Level } 5\end{array}$ & $\begin{array}{l}\text { Very low } \\
\text { rugosity; } \\
\text { very turbid } \\
\text { water; thick } \\
\text { sediment }\end{array}$ & $\begin{array}{l}\text { Absence of } \\
\text { colonies except } \\
\text { highly tolerant } \\
\text { species }\end{array}$ & $\begin{array}{l}\text { No large fish; } \\
\text { only tolerant } \\
\text { species remain; } \\
\text { high abundance } \\
\text { of sediment } \\
\text { dwelling } \\
\text { invertebrates }\end{array}$ & $\begin{array}{l}\text { Small and few } \\
\text { colonies; } \\
\text { highly tolerant } \\
\text { species; high } \\
\text { cover of fleshy } \\
\text { algae }\end{array}$ & $\begin{array}{l}\text { High preva- } \\
\text { lence of dis- } \\
\text { ease and } \\
\text { high tissue } \\
\text { loss }\end{array}$ \\
\hline
\end{tabular}

Simplified from Bradley et al. 2014

the potential list of beneficiaries and associated FEGS can get quite long, some prioritization may be needed to generate a manageable set for further consideration, based on greatest relevance to stakeholders or likelihood of impact by management (see the FEGS Scoping Tool; Sharpe et al. 2020).

Once the FEGS for a given coral reef have been identified, the next step is to develop metrics and indicators for each of the FEGS or the biophysical attributes that provide them. Table 4 below steps through this process for three common groups of human coral reef beneficiaries. The process begins by asking those benefiting from the coral reef what matters directly to them. That information can help identify the type of FEGS necessary to receive that benefit as well as the type of metrics that would be useful. The examples in Table 4 are generic, but more site-specific FEGS and metrics can, and should, be developed for site-specific ESGs. For example, fish diversity and abundance are suggested metrics for the beneficiary category of SCUBA divers. However, alternative or more specific metrics might be more 
Table 4 FEGS metrics for a set of generic coral reef beneficiaries

\begin{tabular}{|c|c|c|c|}
\hline Beneficiary & What matters directly? & $\begin{array}{l}\text { FEGS } \\
\text { type }\end{array}$ & Example metric \\
\hline \multirow[t]{4}{*}{$\begin{array}{l}\text { SCUBA Divers } \\
\text { and Snorkelers }\end{array}$} & $\begin{array}{l}\text { Is there sufficient visibility to be } \\
\text { pleasurable to divers? }\end{array}$ & Water & Secchi disk depth (m) \\
\hline & Is water quality safe for diving? & Water & $\begin{array}{l}\text { Pathogen, contaminant, } \\
\text { toxin concentrations }\end{array}$ \\
\hline & $\begin{array}{l}\text { Do these species attract the } \\
\text { beneficiary? }\end{array}$ & Fauna & $\begin{array}{l}\text { Fish diversity and } \\
\text { abundance }\end{array}$ \\
\hline & $\begin{array}{l}\text { Do these species attract the } \\
\text { beneficiary? }\end{array}$ & Fauna & $\begin{array}{l}\text { Coral diversity and } \\
\text { abundance }\end{array}$ \\
\hline \multirow{4}{*}{$\begin{array}{l}\text { Recreational } \\
\text { Anglers }\end{array}$} & Will I catch what I am expecting? & Fauna & Edible species abundance \\
\hline & Will I catch something interesting? & Fauna & $\begin{array}{l}\text { Charismatic species } \\
\text { abundance }\end{array}$ \\
\hline & Is it safe for boating? & Water & $\begin{array}{l}\text { Wave intensity, surge } \\
\text { height }\end{array}$ \\
\hline & Is this reef aesthetically enjoyable? & $\begin{array}{l}\text { Site } \\
\text { appeal }\end{array}$ & Viewscape, sounds, smells \\
\hline $\begin{array}{l}\text { Coastal Property } \\
\text { Owners }\end{array}$ & Will my property be damaged? & Water & $\begin{array}{l}\text { Flood risk and coastal pro- } \\
\text { tection by the reef }\end{array}$ \\
\hline
\end{tabular}

appropriate, such as the presence or abundance of sea turtles, depending on site-specific factors such local ecology or cultural significance. Expert judgment can be used to determine the most appropriate substitute, depending on local factors as well as data availability. For example, it may not be feasible to collect daily Secchi disk depth readings, but local dive reports on water visibility may be easily collected.

After a complete set of beneficiaries and their associated metrics have been developed, these metrics can be compiled into models like those in Fig. 1 that demonstrate how changes in the level of environmental stress impact these prioritized FEGS. As shown in our coral reef example, there are multiple types of FEGS that may combine with one another to provide the overall benefit to a given beneficiary. For SCUBA diver beneficiaries, metrics related to coral diversity, fish abundance, and water visibility are all important for measuring the level of ecosystem service provided (Fig. 3a). Ecological production functions (EPFs) can be applied (e.g., Yee et al. 2014) to quantitatively link shifts in the level of environmental stress to shifts in the levels of FEGS provided to beneficiaries. One or more FEGS could be assessed for a single beneficiary (Fig. 3a), or those individual FEGS can be combined into an overall measure of realized benefit using ecological benefit functions (EBFs) (Fig. 3b, solid line). Either approach allows for a clear description as to how changes in environmental stressors directly impact different coral reef stakeholder groups (Fig. 3b, dashed lines). 


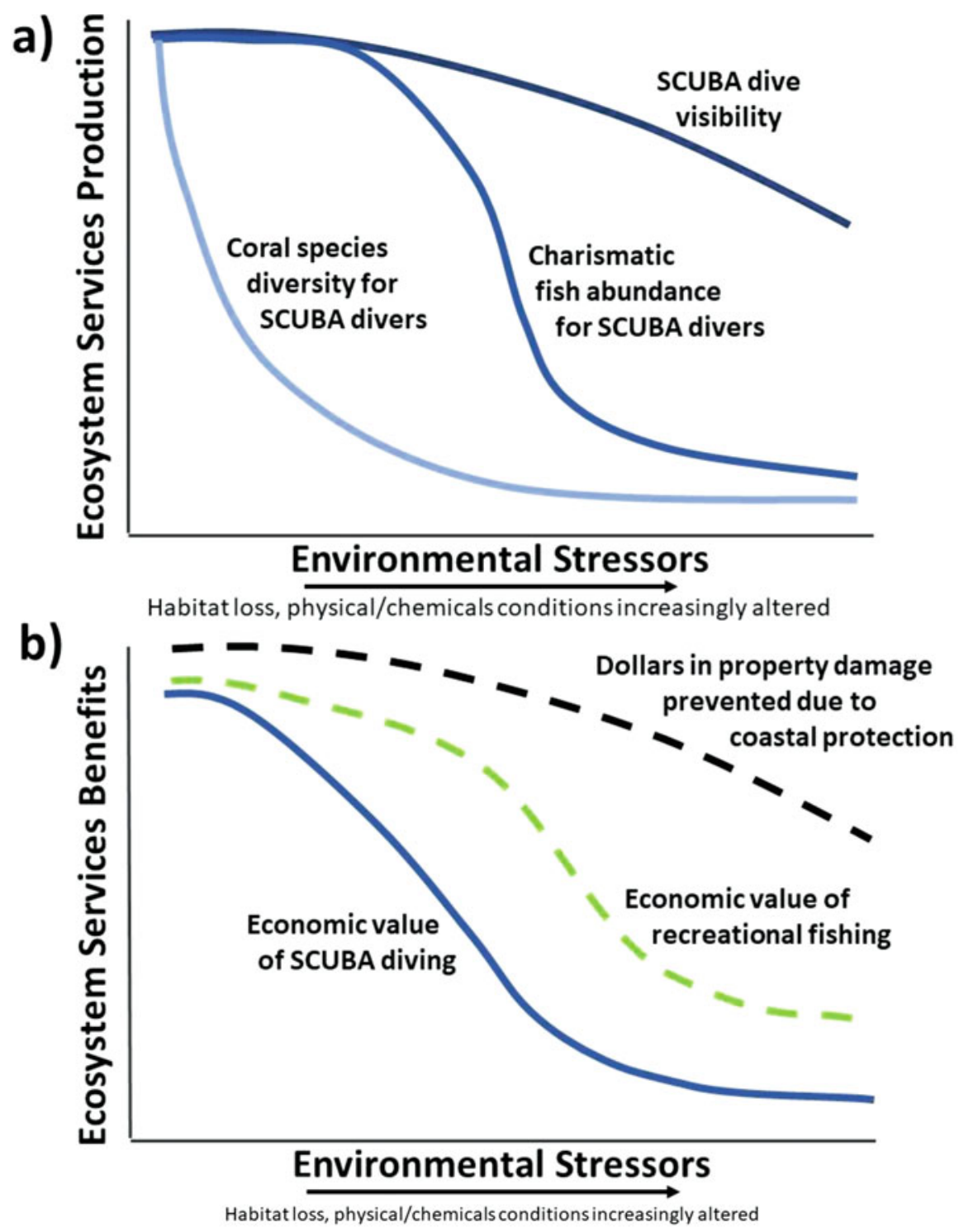

Fig. 3 A hypothetical ESG model showing changes in ecosystem service production and realized benefits in response to increases in environmental stressors. Top panel (a) shows changes in three individual FEGS for a single beneficiary (SCUBA divers) as developed through application of EPFs to changes in environmental attributes. Bottom panel (b) shows realized benefits to SCUBA divers (solid line) in addition to benefits to two other types of coral reef beneficiaries (dashed lines) as developed through application of EBFs to changes in EPFs 


\subsection{Measuring Benefits of Habitat Restoration in Massachusetts Bay}

The Massachusetts Bays National Estuary Program (MassBays) is one of 28 National Estuary Programs (NEPs) across the United States, charged with developing and implementing a long-term plan to improve the waters, habitats, and living resources of their estuary(s). MassBays turned to the BCG framework as part of their plan to identify target conditions to manage 47 embayments along $1770 \mathrm{~km}$ of shoreline. MassBays is planning to use the BCG to communicate condition of key biological components that resonate with the public, including relevant invertebrate, fish, and habitat indicators with which local decision-makers can set public-supported targets. MassBays further realized that presenting community members with socioeconomic information together with BCG biological information would greatly strengthen outreach and lead to better-informed decisions. In the course of updating their long-term plan (MassBays 2019), MassBays sought input on how people use the estuaries. Responses suggest the public cares about estuarine health, clean water and water quality, with favored activities that include shellfishing, swimming, and fishing. Developing a BCG classification scheme and a BCG/ESG approach (Fig. 1) will help to communicate the potential benefits of environmental improvement for both nature and people and to set appropriate, measurable, communitysupported targets for restoration and protection.

As a proposed example of how MassBays could combine BCG and ESG, we focus on seagrass (Zostera marina), a habitat of restoration importance to MassBays. Seagrass beds throughout the MassBays system (and on the entire U.S. coastline) have lost significant area and function due to stressors including nutrient pollution, increasingly extreme weather events, and disease. Seagrasses support a diverse fauna and provide ecosystem services for many beneficiaries. To illustrate the approach, we selected recreational anglers, shellfishers, and birdwatchers as example beneficiaries. Fishing and shellfishing in seagrass beds are popular activities for those seeking striped bass, bluefish, scallops, crabs, and other species. Seagrasses are nursery habitats for many valued species and seagrass beds reliably sustain diving waterfowl for birdwatchers.

The BCG/ESG seen in Fig. 1 as two stacked graphs can also be presented as a Table to better show qualitative and quantitative thresholds of measures that define both the BCG levels of biological condition and the ESG measures of social and economic benefits. Table 5 provides an example of this for seagrass habitat, where the first column identifies each row with BCG level and the second column characterizes the seagrass biology defined by that level as narrative (which could most easily be quantified using seagrass acres as a proxy). The third column lists possible FEGS measures of valued fauna, and the fourth column shows measures of benefits to people. The last three columns align with the three boxes of the conceptual model of Fig. 2. To illustrate management application of Table 5, consider a hypothetical seagrass survey that shows only a few acres of sparse seagrass in a managed area. Sparse seagrass is a Level 5 (fourth row) BCG narrative measure (second column) 
Table 5 A hypothetical example of a seagrass BCG/ESG set up as a table, with possible BCG measures (second column) linked to FEGS measures (third column) linked to benefit measures (fourth column)

\begin{tabular}{|c|c|c|c|}
\hline $\begin{array}{l}\text { BCG } \\
\text { level }\end{array}$ & BCG narrative measures & Possible FEGS measures & Possible benefit measures \\
\hline $\begin{array}{l}\text { Level } \\
1 \text { to } 2\end{array}$ & $\begin{array}{l}\text { Managed area has a large } \\
\text { extent of abundant, dense, } \\
\text { and healthy seagrass that } \\
\text { supports diverse and abun- } \\
\text { dant fauna }\end{array}$ & $\begin{array}{l}\text { Fish/shellfish surveys and } \\
\text { eBird (Sullivan et al. 2009) } \\
\text { show valued fish species } \\
\text { and scallops are very abun- } \\
\text { dant and bird populations } \\
\text { are very diverse }\end{array}$ & $\begin{array}{l}\text { Observations and recrea- } \\
\text { tional fishing surveys } \\
\text { show many people are } \\
\text { fishing, scalloping, or } \\
\text { birdwatching }\end{array}$ \\
\hline $\begin{array}{l}\text { Level } \\
3\end{array}$ & $\begin{array}{l}\text { Some loss of acres from } \\
\text { Level } 1 \text { to } 2 \text { (above); } \\
\text { Abundant, dense, and } \\
\text { healthy seagrass in some } \\
\text { places; Thin and/or poor } \\
\text { quality seagrass elsewhere; } \\
\text { Diverse and abundant fauna } \\
\text { in dense beds }\end{array}$ & $\begin{array}{l}\text { Surveys and eBird show } \\
\text { valued fish species and } \\
\text { scallops are abundant and } \\
\text { bird populations are very } \\
\text { diverse }\end{array}$ & $\begin{array}{l}\text { Observations and recrea- } \\
\text { tional fishing surveys } \\
\text { show many people are } \\
\text { fishing, scalloping, or } \\
\text { birdwatching, comparable } \\
\text { to BCG Level } 1 \text { to } 2 \text { above }\end{array}$ \\
\hline $\begin{array}{l}\text { Level } \\
4\end{array}$ & $\begin{array}{l}\text { Moderate loss of acreage } \\
\text { from Level } 1 \text { to } 2 \text { in man- } \\
\text { aged area; Thin and/or poor } \\
\text { quality seagrass in most } \\
\text { places supports fewer and } \\
\text { less diverse seagrass fauna }\end{array}$ & $\begin{array}{l}\text { Surveys and eBird show } \\
\text { valued fish species and } \\
\text { scallops are moderately } \\
\text { abundant and bird } \\
\text { populations are diverse }\end{array}$ & $\begin{array}{l}\text { Observations and recrea- } \\
\text { tional fishing surveys } \\
\text { show a moderate number } \\
\text { of people are fishing, } \\
\text { scalloping, or } \\
\text { birdwatching }\end{array}$ \\
\hline $\begin{array}{l}\text { Level } \\
5\end{array}$ & $\begin{array}{l}\text { Major loss of acres from } \\
\text { Level } 1 \text { to } 2 \text { in managed } \\
\text { area; Sparse seagrass sup- } \\
\text { ports sparse fauna }\end{array}$ & $\begin{array}{l}\text { Surveys and eBird show } \\
\text { valued fish species and } \\
\text { scallops are scarce and bird } \\
\text { population diversity is only } \\
\text { slightly elevated from adja- } \\
\text { cent non-vegetated areas }\end{array}$ & $\begin{array}{l}\text { Observations and recrea- } \\
\text { tional fishing surveys } \\
\text { show few people fishing, } \\
\text { scalloping, or } \\
\text { birdwatching }\end{array}$ \\
\hline $\begin{array}{l}\text { Level } \\
6\end{array}$ & $\begin{array}{l}\text { No seagrass, shift to less } \\
\text { diverse and productive } \\
\text { non-vegetated faunal com- } \\
\text { munities in managed area }\end{array}$ & $\begin{array}{l}\text { Fish, scallop, and bird } \\
\text { populations are comparable } \\
\text { to those in non-vegetated } \\
\text { areas }\end{array}$ & $\begin{array}{l}\text { No more people are fish- } \\
\text { ing, scalloping, or } \\
\text { birdwatching than in local } \\
\text { non-vegetated areas }\end{array}$ \\
\hline
\end{tabular}

with scarce valued fauna, and few people enjoying benefits (third and fourth columns). Presenting this information to the public together with descriptions of better environmental and socio-economic conditions at higher BCG levels could inspire a long-term vision of achieving, say, Level 3 conditions (second row) with abundant seagrass and fauna and many fishers and birdwatchers in some but not all places within the managed area. Once quantitative targets are set (e.g., for Level 3 acres) public-supported management actions (perhaps significant nutrient reductions) can be developed and implemented, then changes in BCG, FEGS, and benefit measures can be quantitatively monitored and reported back to the public.

The success of this potential approach for MassBays depends on the data and effort utilized to create a working BCG/ESG gradient that could apply at several scales: an overarching application to all 47 embayments; application to groups of embayments classified based on specific characteristic conditions; and to 
embayments at scales most relevant to management. Key elements of the effort are acquiring data and determining appropriate reference narratives and values for biological, FEGS, and benefit indicators. Comparability of the approach among embayments relies on a consistent identification of Level 1 or combined Level 1 / Level 2 condition.

To address data needs, MassBays worked with partners to synthesize a large amount of environmental, social, and economic data for these embayments. Reference condition for seagrass acres may be available through historic maps, charts, and surveys, or (as with all measures) by using best available current data, which may not represent Level 1 or 2 , but can be interpreted in the BCG construct as Level 3 (or lower). It is likely that other existing MassBays data might serve as proxies for FEGS measures (here fishing, shellfishing, and birdwatching) based on methods in the literature, such as Rapid Benefits Indicators (e.g., Mazzotta et al. 2016).

Combining the BCG with an assessment of ecosystem services allows communication of environmental condition directly linked to the socio-economic benefits of environmental improvement (Cicchetti et al. 2017). This approach can resonate with people whose belief systems run the entire spectrum from those who most appreciate nature for its own sake to those who most appreciate the socio-economic benefits that nature provides to humans. Engaging a range of stakeholders invests more people in the value of environmental protection and is an important tenet of ecosystem-based management (Arkema et al. 2006). The BCG/ESG framework captures stakeholder input to develop goals using the approach of "what did we have, what do we have, what do we want, and how do we get there" to communicate both nature and benefits (Tables 1 and 2). This allows managers to set appropriate, measurable environmental targets that are supported by a diverse public.

\section{Role of an ESG in Ecosystem-Based Management}

The introduction of ecosystem goods and services advances the utility and applicability of the BCG framework for ecosystem-based management activities. Important action items within an EBM approach to decision making can include: the identification of objectives and performance measures to describe what really matters to stakeholders about a decision; the identification of management alternatives; the articulation of potential user conflicts or tradeoffs between management alternatives; and the articulation of potential direct ecosystem services benefits, or related co-occurring benefits, for a given decision context (Cormier et al. 2017). The ESG, through its structured approach to defining and enumerating potential changes in ecosystem services, allows decision makers to clearly articulate the elements feeding into each of these steps.

An important foundational principle of the BCG is science communication through BCG visualization and the accompanying tables that describe the technical aspects of each BCG level. Likewise, an ESG framework also lends itself to strong science communication served up in a strategic manner (sensu Harwell et al. 2020), 
allowing for communication of key messages to targeted audiences. Paired with a BCG, the ESG can allow decision makers to describe meaningful and unambiguous environmental objectives and their measures and clearly communicate the potential gains or losses in ecosystem services. The quantitative measures defined by the levels of an ESG might also indicate where biomonitoring can be used to assess whether actions are having the desired outcomes and what adjustments can be made to future actions as part of targeted adaptive management efforts (e.g., LoSchiavo et al. 2013).

Finally, the ESG approach can be helpful for identification of critical gaps in knowledge, helping EBM practitioners identify where resources may be needed to fill those gaps - in particular, what future scientific research is needed to move a narrative description for a given ESG level to a quantitative description. Future development of ESG principles include in-depth application to a suite of case study examples across a range of ecosystem types, both related to information and regulatory needs, such as condition assessments conducted for water quality management purposes under the U.S. Clean Water Act, and to broader EBM questions such as ecological protection, restoration or fisheries management.

Disclaimer This chapter has been subjected to Agency review and has been approved for publication. The views expressed in this paper are those of the author(s) and do not necessarily reflect the views or policies of the U.S. Environmental Protection Agency.

\section{References}

Arkema, K. K., Abramson, S. C., \& Dewsbury, B. M. (2006). Marine ecosystem-based management: from characterization to implementation. Frontiers in Ecology and the Environment, 4, $525-532$.

Boyd, J. W., Ringold, P. L., Krupnick, A. J., Johnston, R. J., Weber, M., \& Hall, K. (2015). Ecosystem services indicators: Improving the linkage between biophysical and economic analyses. RFF DP 15-40. Washington, DC: Resources for the Future.

Bradley, P., Santavy, D. L., \& Gerritsen, J. (2014). Workshop on biological integrity of coral reefs August 21-22, 2012, Caribbean Coral Reef Institute, Isla Magueyes, La Parguera, Puerto Rico. EPA/600/R-13/350. Narragansett, RI: U.S. Environmental Protection Agency, Office of Research and Development, Atlantic Ecology Division.

Bruins, R. J. F., Canfield, T. J., Duke, C., Kapustka, L., Nahlik, A. M., \& Schäfer, R. B. (2017). Using ecological production functions to link ecological processes to ecosystem services. Integrated Environmental Assessment, 13(1), 52-61.

Cicchetti, G., Pelletier, M. C., Rocha, K. J., Bradley, P., Santavy, D. L., Pryor, M. E., Jackson, S. K., Davies, S. P., Deacutis, C. F., \& Shumchenia, E. J. (2017). Implementing the biological condition gradient framework for management of estuaries and coasts. EPA/600/R-15/287. Narragansett, RI: U.S. Environmental Protection Agency, Office of Research and Development, Atlantic Ecology Division.

Cormier, R., Kelble, C. R., Anderson, M. R., Allen, J. I., Grehan, A., \& Gregersen, O. (2017). Moving from ecosystem-based policy objectives to operational implementation of ecosystembased management measures. ICES Journal of Marine Sciences, 74, 406-413.

Davies, S. P., \& Jackson, S. K. (2006). The biological condition gradient: A descriptive model for interpreting change in aquatic ecosystems. Ecological Applications, 16, 1251-1266. 
DeWitt, T. H., Berry, W. J., Canfield, T. J., Fulford, R. S., Harwell, M. C., Hoffman, J. C., Johnston, J. M., Newcomer-Johnson, T. A., Ringold, P. L., Russel, M. J., Sharpe, L. A., \& Yee, S. J. H. (2020). The final ecosystem goods and services (FEGS) approach: A beneficiarycentric method to support ecosystem-based management. In T. O'Higgins, M. Lago, \& T. H. DeWitt (Eds.), Ecosystem-based management, ecosystem services and aquatic biodiversity: Theory, tools and applications (pp. 127-148). Amsterdam: Springer.

Gregory, R., Failing, L., Harstone, M., Long, G., McDaniels, T., \& Ohlson, D. (2012). Structured decision making: A practical guide to environmental management choices. Chichester, UK: Wiley-Blackwell.

Haines-Young, R., \& Potschin, M. B. (2018). Common International Classification of Ecosystem Services (CICES) V5.1 and guidance on the application of the revised structure. Nottingham, UK: Fabis Consulting.

Harborne, A. R., Rogers, A., Bozec, Y.-M., \& Mumby, P. J. (2017). Multiple stressors and the functioning of coral reefs. Annual Review of Marine Sciences, 9, 445-468.

Harwell, M. C., Molleda, J. L., Jackson, C. A., \& Sharpe, L. (2020). Establishing a common framework for strategic communication in ecosystem-based management and the natural sciences. In T. O'Higgins, M. Lago, \& T. H. DeWitt (Eds.), Ecosystem-based management, ecosystem services and aquatic biodiversity: Theory, tools and applications (pp. 165-188). Amsterdam: Springer.

Landers, D., \& Nahlik, A. (2013). Final ecosystem goods and services classification system (FEGSCS). EPA/600/R-13/ORD-004914. Washington, DC: U.S. Environmental Protection Agency.

Link, J. S., \& Browman, H. I. (2017). Operationalizing and implementing ecosystem-based management. ICES Journal of Marine Sciences, 74, 379-381.

LoSchiavo, A., Best, R., Burns, R., Gray, S., Harwell, M., Hines, E., McLean, A., St. Clair, T., Traxler, S., \& Vearil, J. (2013). Lessons learned from the first decade of adaptive management in comprehensive Everglades restoration. Ecology and Society, 18, 70-85.

MassBays, Massachusetts Bay National Estuary Program. (2019). Comprehensive conservation and management plan: A blueprint for the bays. Boston, MA: Massachusetts Bay National Estuary Program.

Mazzotta, M., Bousquin, J., Ojo, C., Hychka, K., Druschke, C. G., Berry, W., \& McKinney, R. (2016). Assessing the benefits of wetland restoration: A rapid benefit indicators approach for decision makers. EPA/600/R-16/084. Narragansett, RI: U.S. Environmental Protection Agency.

McLeod, K. L., Lubchenco, J., Palumbi, S. R., \& Rosenberg, A. A. (2005). Scientific consensus statement on marine ecosystem-based management. Communication Partnership for Science and the Sea. Retrieved October 22, 2019, from http://www.coml.us/wp-content/uploads/2010/ 06/Scientific-Consensus-Statement-on-Marine-Ecosystem-Based-Management.pdf.

Moberg, F., \& Folke, C. (1999). Ecological goods and services of coral reef ecosystems. Ecological Economics, 29, 215-233.

Principe, P., Bradley, P., Yee, S., Fisher, W., Johnson, E., Allen, P., \& Campbell, D. (2012). State of the science on linkages among coral reef condition, functions, and ecosystem services. EPA/ 600/R-11/206. U.S. Research Triangle Park, NC: Environmental Protection Agency, Office of Research and Development.

Santavy, D. L., Bradley, P., Gerritsen, J., \& Oliver, L. (2016). The biological condition gradient, a tool used for describing the condition of US coral reef ecosystems. Proceedings of the 13th International Coral Reef Symposium, Honolulu, pp. 548-559.

Sharpe, L., Hernandez, C., \& Jackson, C. (2020). Prioritizing stakeholders, beneficiaries and environmental attributes: A tool for ecosystem-based management. In T. O'Higgins, M. Lago, \& T. H. DeWitt (Eds.), Ecosystem-based management, ecosystem services and aquatic biodiversity: Theory, tools and applications (pp. 189-212). Amsterdam: Springer. 
Sullivan, B. L., Wood, C. L., Iliff, M. J., Bonney, R. E., Fink, D., \& Kelling, S. (2009). eBird: A citizen-based bird observation network in the biological sciences. Biol Conserv, 142(10), 2282-2292.

U.S. EPA. (2015). National ecosystem services classification system (NESCS): Framework design and policy application. EPA-800-R-15-002. Washington, DC: United States Environmental Protection Agency.

U.S. EPA. (2016). A practitioner's guide to the biological condition gradient: A framework to describe incremental change in aquatic ecosystems. EPA-842-R-16-001. Washington, DC: U.S. Environmental Protection Agency.

van Beukering, P., Brander, L., van Zanten, B., Verbrugge, E., \& Lems, K. (2011). The economic value of the coral reef ecosystems of the United States Virgin Islands. Report R11/06. Amsterdam: IVM Institute for Environmental Studies.

Wainger, L., \& Mazzotta, M. (2011). Realizing the potential of ecosystem services: A framework for relating ecological changes to economic benefits. Environmental Management, 48, 710-733.

Wilkinson, C. (2008). Status of coral reefs of the world: 2008. Townsville, Australia: Global Coral Reef Monitoring Network and Reef and Rainforest Research Centre.

Yee, S. H., Dittmar, J. A., \& Oliver, L. M. (2014). Comparison of methods for quantifying reef ecosystem services: A case study mapping services for St. Croix, USVI. Ecosystem Services, 8, $1-15$.

Yee, S., Bousquin, J., Bruins, R., Canfield, T. J., DeWitt, T. H., de Jesús-Crespo, R., Dyson, B., Fulford, R., Harwell, M., Hoffman, J., Littles, C. J., Johnston, J. M., McKane, R. B., Green, L., Russell, M., Sharpe, L., Seeteram, N., Tashie, A., \& Williams, K. (2017). Practical strategies for integrating final ecosystem goods and services into community decision-making. EPA/600/ $R-17 / 266$. Gulf Breeze, FL: U.S. Environmental Protection Agency.

Open Access This chapter is licensed under the terms of the Creative Commons Attribution 4.0 International License (http://creativecommons.org/licenses/by/4.0/), which permits use, sharing, adaptation, distribution and reproduction in any medium or format, as long as you give appropriate credit to the original author(s) and the source, provide a link to the Creative Commons licence and indicate if changes were made.

The images or other third party material in this chapter are included in the chapter's Creative Commons licence, unless indicated otherwise in a credit line to the material. If material is not included in the chapter's Creative Commons licence and your intended use is not permitted by statutory regulation or exceeds the permitted use, you will need to obtain permission directly from the copyright holder.

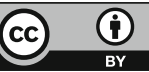

